\title{
Quo Vadis Administrative Discretion
}

\author{
${ }^{1}$ Laurens Bulo \\ 2Margaretha Ratulangi \\ ${ }^{3}$ Arody Tangkere \\ ${ }^{4}$ Haedar Akib \\ 5 Jasruddin \\ ${ }^{1}$ Doctoral Candidate of Public Administration, Universitas Negeri Makassar UNM \\ ${ }^{2}$ Doctor of Public Administration in Universitas Negeri Makassar UNM \\ ${ }^{3}$ Doctoral Candidate of Public Administration Science in Universitas Negeri Makassar UNM \\ ${ }^{4}$ Associate Professor, Public Administration, Universitas Negeri Makassar UNM \\ ${ }^{5}$ Associate Professor, Physics Education, Universitas Negeri Makassar UNM Indonesıa \\ Emails: ${ }^{1}$ laurensbulo@yahoo.com, ${ }^{2}$ margaretharatulangi@hotmail.com, ${ }^{3}$ arodiareli@yahoo.com \\ 4Haedar652002@yahoo.com,5mahande64@yahoo.com
}

\section{Doi:10.5901/mjss.2016.v7n1s1p25}

Abstract

\begin{abstract}
The trend happening in the era of this autonomy is that replacement of structural officials always follows any change of both the Governor and the Regional Head of Regents and Mayors through rolling mechanism. Officials who are considered not to support in local elections or deemed to have no supporter will be stopped from their structural positions. While the officials who serve as team success in the local elections will be appointed as structural officials although they do not meet the requirements both in terms of rank, seniority, professionalism, experience and competence in any position. This study aimed at analyzing and explaining the effectiveness of administrative discretion in the appointment of personnel to structural positions. This research used qualitative descriptive research with a phenomenological approach. The results showed that the mayor administrative discretion is effective in interfering recommendation of Baperjakat or Board of Advisory Position and Rank on the recruitment process of personnel in structural position in order to get the structural officials who are not competent in the structural position they occupied in the City of Tomohon.
\end{abstract}

Keywords: regional head, Baperjakat, administrative discretion, structural officials.

\section{Introduction}

Mayor has creative innovation space through administrative discretion to bring officials that have competence in carrying out their responsibility in Governance, Development and Welfare of society in Tomohon. However, there are some regional heads who consider that the discretion is an entrapment for them. There are any regional heads who have to sit in prisoner chairs because of entangled in corruption or the administrative court by their officials as it is considered to act arbitrarily in using its power as regional head as well as officials of Trustees Personnel.

Administrative discretion is a multi-faced in the sense that it can be positive or negative for any decision taken by the regional head, especially in appointing officials to the structural positions. Administrative discretion is used positively in the sense of the use of the domain power possessed by a regional head. Therefore, if it is used in the rules and regulations of existing staffing and the merit system, then the decision is to produce structural recruitment of competent officials and it is referred as creative innovation space. In otherwise, the administrative discretion that possessed by each regional heads where the implementation is based on power only to influence political interests, cultural patronage and spoil system then it will make a decision that will not produce structural competent officials, and this space is called as an arrogance of power or abuse of power.

Regional heads have to understand the essence of power. Thus, there is no mistake in taking any decision on the appointment of officials in structural positions because the administrative discretion is very effective in interfering recommendation of Baperjakat (Badan Pertimbangan Jabatan Dan Kepangkatan/Board of Advisory Position and Rank) in 
the recruitment of structural officials. Criteria for the designation of an official in a structural position has been clearly managed in Government Regulation of the Republic of Indonesia Number 13, 2002 about Amendment to the Government Regulation No. 100, 2000 about Appointment of Civil Servants In Structural Position, with the execution of Decree of the Head of State Personnel Board No. 13, 2002.

\section{Literature Review}

Many experts give the definition of authority, including Budiardjo. He states that power is personal or group ability to influence other individual or group behavior by the wishes of the person or group. Meanwhile, according Surbakti power is the capacity to influence others to think and behave by the wishes of influence.

According to Stout, as reaffirmed by Patiro, power is derived from a legal definition of government organization. It can be explained as a whole rule that is pleased with the acquisition and use of government power by public law subjects in public law relationships. Furthermore, Tonnaer reveals that in the governmental power this connection is considered as the ability to implement a positive law and thus it can be created a legal relationship between government and citizen".

Thoha said that the power can be formulated as a special type of power that originally attached to the positions occupied by the leader. Thus, the power is authorized power (legitimatized) by a formal role of a person in an organization. A government without the inherent power is not the rational government because the government as it is not empowered to arrange, organize and direct the people that would be brought to an extent. Power is the completeness that makes authoritative government in the presence of people.

Excessive power without being based on the underlying rules would be a crime. Therefore, the power is often seen as bad things. Such thing has led to the trend that blurs the basic truth and functions of organizational power. As in recent years, there has been a change in such thing. Hicks and Gullet. Berle describes the opinion of Lord Acton that power tends to corrupt, and absolute power corrupts absolutely. This statement reinforces the frequent opinion obtained by the holders of power that should be considered as potential opponents and plunderers of the civil rights. Thus, based on this view, the power will be challenged as morally considered disgusting.

In carrying out an authority, governments always do policy in the form of a decision, including administrative discretion. According to Saputra, discretion can be called as freedom that is given to the state administrative apparatus, namely the freedom it allows prioritizing the effectiveness of the state administration tool to achieve a goal of at sticking to the law, or the lawful power to meddle in social activities in order to perform the duties of organizing the public interest. Therefore, an official of the state administration in carrying out tasks in the public interest should not only dependent or based on whether or not a rule. Meanwhile, according to Effendi, discretion is the power of the government to take a decision and to do acts that are not regulated by legislation. However, it is justified under certain conditions with the aim to carry out its duties and functions on the basis of general principles of good governance.

\section{Methods}

Referring to the subject matter and purpose of the study, this study uses qualitative research, with the phenomenological approach. Descriptive qualitative research method was chosen because it is in accordance with the suitability criteria of researchers on the assumption of ontological assumptions, epistemological, axiological, rhetorical and methodological of the qualitative paradigm.

This research used qualitative descriptive research. The aim of this research was to analyze and to explain the effectiveness authority of Mayor administrative discretion in the appointment of an official in structural positions according to the Government Regulation No. 13, 2002. Data sources were written materials in the form of government regulations, local regulations, local government policies, materials and reports of other archives that relevant in this study. The informants consisted of (a) Key informant, namely Mayor of Tomohon, Tomohon City Council Chairman, and the Chairman and members of the Advisory Board Position and Rank or Baperjakat, (b) Supporting informant, namely; Community Leaders, Community Members, Press and Non-Government Organization in Tomohon.

The researchers were the main instrument. They collected data through interviews and observations, data analysts and providers of the meaning of the phenomenon of the research data. The process of data analysis in this research was implemented at the beginning of data collection activities till the finding theme process. In analyzing the research data, the analysis refers to the advanced theory of Milles and interactive model of Huberman. 


\section{Results}

In carrying out the duties of government and community development, the regional head in charge of the mandate given by the people who choose him or her as the Mayor where he or she should be helped by the competent officials and who have competencies that required from the structural position. In the recruitment of staff members, the Mayor would be assisted by Baperjakat (Board of Advisory Position and Rank) that will give consideration to the appointment, dismissal and removal the officials in a structural position normatively. However, in its implementation, the result of structural official appointment is not in accordance with required competencies. It is happened because of interference by the mayor through its administrative discretion as Trustees Personnel Officer. In addition to the influence of political factors, nepotism, patronage, spoils system is still applied in the civil service career system where the officials are not competent in their positions, and other causes were (a) data officer and (b) closed recruitment system.

\subsection{Personnel Data}

An accurate personnel data is an important source of information for the development of career government officials. Recently, the Order List Ranks is very difficult to be seen by every employee, even though this document is crucial. Through these data, an employee can see his or her position and the career of other civil servants. Order List Ranks become one of the assessment standard by Baperjakat in looking at the potential who possessed by an official for the proposed structural positions. Nevertheless, the results of the research showed that Order List Ranks cannot be seen openly by each official and by limited circle only. Thus, the existing civil servants do not know how their position in the personnel management, in order to improve competence, they are not motivated because they do not see the competition climate.

The accessibility of personnel documents provides safety and comfort feeling for an employee because he knows his position and other positions in personnel management of government agencies. Therefore, when someone proposed to occupy a position, other officials can assess the feasibility normatively in real terms. Thus, the career enhancement in the form of official promotion will not cause jealousy from other officials who actually deserve to be promoted in the sense of availability data that can be accessed easily by providing opportunities for each official to compete fairly through the efforts to repair the ability personally.

According to most officials, positions are more obtained by the proximity to the regional head than by work performance in the execution of duties. It happens because the officials do not see the order number of the official position on Order List Ranks. Therefore, the Order List Ranks is twisted into Order List Closeness because the opportunity to become officials is easier by doing proximity through various means against the mayor or even following what the mayor wants.

\subsection{Promotion Policy}

In carrying out vision and mission of a new mayor, it is necessary for structural officials who have the ability to run Regional Working Unit. In recent tradition, the trend happened for every turn of regional head, then the subordinates should be also replaced and the reason is because the officials "do not have the ability" or "not in line" or other reasons that are considered as rational reasons. Substitution of bureaucratic is not only valid in the districts/cities in Indonesia, even in a developed country like United States. This trend also occurred to Andrew Jacksons, when he became President of America, 90 percent of the old officials appointed by the Quincy Adams, were replaced by his subordinates.

Research shows that in 2009, it was performed the inauguration of the second echelon as many as 26 people, group IV/a with 3 people and a number of group IV / b as many as 23 people while as many as 3 people are not in any job, and there are three people that appointed in positions that are not in accordance with their competence.

In 2010, it was carried out the inauguration at the Echelon II as many as 21 people, group IV/a with 2 people and group IV/b as many as 23 people while as many as 6 people consisting of 3 group IV/c and 3 people for group IV / b senior are not in any job, There are two people appointed to positions that are not in accordance with their competence. Inauguration in 2010 coincided with the turn of a new regional head, doing by the Interior Minister and the Governor because of his inauguration carried out in prisons.

In 2011, it was conducted the inauguration at the Echelon II as many as 21 people, there is a group IV / 4 people and a number of group IV / b as many as 17 people while as many as four people Group IV / $\mathrm{C}$ are not in any job, and three people appointed to the positions that are not in accordance with their competence.

The trend about official recruitment is indicated from the research results. The result showed that every time there 
is always a raised inauguration that is not in accordance with required competencies of the positions and there were even senior official that removed from office without knowing the mistake he had done. The dismissal of a structural position normatively means that the officials do a serious offense. Therefore, the personnel regulations need to be developed, one of them is through dismissal position.

\section{Discussion}

Definition of Disclosure (openness) is the availability of data or information for the community that can be accessed in accordance with the legislation. Disclosure also refers to the availability and clarity of information for the general public to know the creation, implementation, and results that have been achieved through a public policy. While definition of transparency is opened for public participation.

Application of the openness and transparency principle in personnel management is intended to the accessible personnel document. Meanwhile, the process of formulation of the names to be proposed should be known by all the existing officials. Therefore, it will be seen whether everyone knows the promoted staffs that registered in Order List Rank and included in a track record. Thus, all decisions taken by Trustees Personnel Officers can be accepted well by all the civil servants. If there is ambiguity in the selection process, it will soon be known by all officials, and those who feel cheated will give reaction because it has proof.

According to Bappenas (National Development Planning Board) all affairs of governance in the form of public policies whether it refers to public services or it refers to the local development must be known by the public. They should easily understand and obtain data and information about policies, programs, and activities of local governments and legislators. The contents of decision and reasons of public policy-making should be accessible to the public, and must be announced in order to get a public response. Similarly, information about the implementation of policy and its results, must be open and accessible to the public. In this context, government officials should be willing to openly and honestly to provide the necessary information for public.

Because of the availability of personnel data that is accurate and easily to access by anyone who accompanied by a transparent recruitment process, it is expected that the use of discretionary power of the mayor in the placement of structural officials will produce qualified personnel. The use of discretionary power to disclose information will provide a comfortable atmosphere for the officials because they feel treated fairly in the development of their careers. Therefore, discretionary power can encourage personnel management towards more quality in the recruitment of structural officials.

The discussion above can be summarized from the results of observation, interviews and critical examination where the personnel management is closed and exclusive. However, it gives negative usage of administrative discretion because the proposed official in Baperjakat recommendation is based on invalid personnel data staffing and subjective assessment.

According Thoha, there are many problems that now faced by government bureaucracy. The first is patron-client $(\mathrm{KKN})$ in the government bureaucracy. There is an obstacle to achieving meritocracy in bureaucracy. The second is unclear government bureaucracy. It tends no sense of accountability whether it is institutionally or individually. The third is bureaucratic positions that accommodate only limited structural and filling are often not based on the required competencies. The fourth is the arrangement of personnel resources that are not adapted to the needs and institutional bureaucracy structure.

The statement above gives an understanding that the problem of recruitment in order to promote an official in an office, is one way to get out of the bureaucratic problems that exist today. As the researchers say that the use of discretion by the power will be an innovation space where the mayor can choose from Baperjakat recommendation about the officials that are eligible and deserve to be promoted. Some regions in Indonesia have made a significant innovation through a discretion that is owned by a local chief to conduct promotion policy. There are various terms that used for the promotion policy such as job auction and Job tender. In the formal judicial, there are still no rules that support the innovation, but the goal is for public use and repaired officials that edges for better governance, then several regional heads have done improvisation for the recruitment in this way.

Therefore, according Saputra, discretion can be called a freedom that is given to the state administration tools, namely the freedom that allows prioritizing the effectiveness of the state administration tool to achieve a goal that refers to the law, or the lawful power to intervene in social activities in order to carry out the tasks to organize the public interest. Thus, an official of the state administration in carrying out tasks in the public interest should not only dependent or based on whether there is a rule or not.

Some areas in Indonesia, after Jakarta government made a decision about administrative discretion in hiring officials with street level bureaucracy (vanguard) which are village chiefs in 2013 and followed by the Governors of 
Central Java, East Kalimantan, South Sulawesi and Regents of Tegal, Maros, Kupang, Aceh and some other areas in Indonesia, which also have started this recruitment models since 2013.

Job auction becomes a new trend for the provincial government and districts or cities in Indonesia with developed and clean thoughts to obtain a reliable and professional personnel. In other side, this model minimizes the "deposit" of the political elite, officials and though the people who have influence in government.

Promotion policy aims to make openness and transparency in the recruitment of structural officials through healthy competition among the state officials so that elected officials can work professionally and optimally in carrying out their responsibilities. The most important is removing the factors of like and dislike in the placement of structural officials and familiarize them in a change of bureaucracy climate from the comfort to the competitive zone.

One of the action plan 9 (Nine) of Bureaucracy Reformation Acceleration Programs is opened Civil Servants Promotion System Program. In relation to the above provision, in order to ensure the structural officials meet job with required competence, there should be promotion of civil servants or filling a vacancy which is based on merit and open systems, by considering the record of civil servant careers.

According to Kasim (2007), in the literature about civil servants, there is technical term known as spoils system and merit system. The spoils system is staffing practice that emphasizes loyalty, patronage and equity interests (political and others). Spoils system requires that the principle of tenure of civil servants is limited so that the political leaders (elected Officials) will have an opportunity to appoint new public servants from among his followers. While the merit system is staffing practice that emphasizes the principles of objectivity, fairness and competency-based. Merit system requires civil servants as career officials that are competent and neutral in serving anyone who becomes political leaders, no matter what their political party or flow.

The principle of spoil system has been used in recruiting civil servants to structural positions. There are many flaws in this system such as the closed activities that conducted by Baperjakat in implementing structural official candidate selection process. With this closure, the chance to manage an apparatus that is not competent or prospective "surrogate" is not in accordance with Oder List Ranks that can be freely performed. Because of the Order List Ranks are a rare commodity to be seen by civil servants who work in these agencies, the document is only a formality that includes recommendations from Baperjakat. However, with the power that possessed by the mayor, he or she may reject the results of the recommendation, or propose other names to be discussed with Central Government that refers to the reformation of the bureaucracy that has issued the Circular Letter of Minister of Administrative and Bureaucratic Reform of the Republic of Indonesia No. 16 in 2012 on Procedures Charging The Structural Position Vacant Openly in Environmental Government Agencies. The Circular Letter of Minister can give new nuances in promotion policy for each district or city. However, it is all coming back to the political will from a regional head in using his or her power in administrative discretion. Tomohon City Government is expected to support the availability of accurate personnel data in order to provide proper information for Baperjakat to present recommendations to the Mayor. The availability of accurate data is expected to be accessible for all personnel and it must also be offset by recruiting openly through the Mayor's discretion as legality. Furthermore, through this process, the mayor used the discretion power to choose an official to be placed in a structural position that corresponds to the required competency.

The discussion and analysis of this study can be summarized by assuming that the administrative discretion becomes effective on the appointment of the officials in a structural position that is supported by valid personnel data online to support the recruitment of structural official in Human Resources Management System. Furthermore, researchers can construct a proposition that: Administrative discretion is based on power, and the responsibility is innovation space. Administrative discretion is based on the rule that refers to the power arrogance space.

\section{Conclusion}

Administrative discretion of Mayor is effective in intervene the Baperjakat recommendation on the process of personnel recruitment in the structural position to gain structurally incompetent officials appropriate with the structural position they occupied. It can happen because the authority of administrative discretion attached to the mayor because of his position, therefore, these powers are active in every decision of a public policy that will be applied, including the appointment of personnel at a structural position as one of the implementations of the Civil-Service Management functions. Because of this, authority is very subjective; the impact of the implementation of governance and development is highly dependent on the political will of the Mayor itself to implement the principle of the right man on the right job in order to establish good governance in Tomohon. 


\section{References}

Bappenas. (2007). The Implementation Of Good Governance. Jakarta: Ministry of National Development Planning/National Development Planning Board (Bappenas).

Berle, A. (1969). Power. New York: Harcourt, Brace \& World.

Budiardjo, M. (2002). Basics of Political Science. Jakarta: PT. Gramedia Pustaka Utama.

Decree of the Head of State Personnel Board No. 13, 2002, Concerning The Implementation Of The Indonesian Government Regulation Number 13, 2002.

Effendi, T. (2013). Bureaucracy Reforms and Investment Climate. Jakarta: Constitutional Press.

Henry, N. (1995). Public Administration and Public Affair. Translated by Lontoh, LD. Jakarta: PT Raja Grafindo Persada.

Hicks, GH \& Gullet, CR. (1987). Organizational Theory and Behavior. Translated by Kartasapoetra, G \& Kartasapoetra, AG. Jakarta: Earth Literacy.

Patiro. IMY. (2012). The discretion of Public Officials and Corruption Crime. Bandung: Publisher CV Keni Media.

Saputra.(1998). The State Administration Law. Jakarta: Rajawali Press.

Surbakti, Ramlan. (1992). Understanding the Political Science. Jakarta: Gramedia.

The Indonesian Government Regulation Number 13, 2002 on Amendment of Government Regulation No. 100, 2000 About Appointment of Civil Servants in structural positions, with the execution of the provisions of Decree of the Head of State Personnel Board No. $13,2002$.

Thoha, M. 2005. Management of Civil Service in Indonesia. Jakarta: Prenada Media.

Thoha, M. 2011. Organizational Behavior: Basic Concepts and Applications. Jakarta: PT. Raja Grafindo Persada.

Priyatno, M. (2013). Reconstruction Of Meritocracy In Placement Officer in the Republic of Indonesia: SSM Application-Based Action Research in the Three Level Institutional. unpublished. Jakarta : Doctoral Dissertation, University of Indonesia. 